\title{
Foreword
}

\section{ISABE and the 2017 symposium}

Propulsion systems have revolutionised human activities and made the world smaller. They have brought transport advances that enabled the conversion of dreams into reality. Very large international high-technology investments are being made to continue to develop efficient and affordable gas turbine and ramjet propulsion while implementing knowledge that is bringing large environmental benefits.

The International Society for Air Breathing Engines (ISABE) was founded in 1972 to bring together the international community that brought and continues to bring together these changes. Professor Valensi from Institut de Mécanique des Fluides de Marseille and Dr J. Bubb from Wright-Patterson Air Force Base concluded that there was insufficient international coverage to discuss air-breathing propulsion. It was agreed, after the International Council for Aerospace Sciences (ICAS) meeting in 1970 in Rome, to organise a symposium and to continue, depending on the response, on a voluntary basis. Professor Valensi offered to hold the first symposium in Marseilles, France in 1972. The people involved came from a group of high-speed propulsion specialists, especially those who were ramjetoriented. Generous support was received from the Aeronautical and Astronautical Society, the Mechanical Engineering Society and the Research and Test Directorate of France. The EOAR in London has also been a sponsor for many years. We would like to acknowledge the generous support the Society has enjoyed from the different national and international organisations over the years. The concept was to be truly international and move around the globe with the ISABE Symposium/Conference. The organisation should be given to another country/continent on a two-year cycle. The first symposium was organised from 19-23 June 1972 in Marseilles, France, by Professor Valensi under the auspices of ICAS.

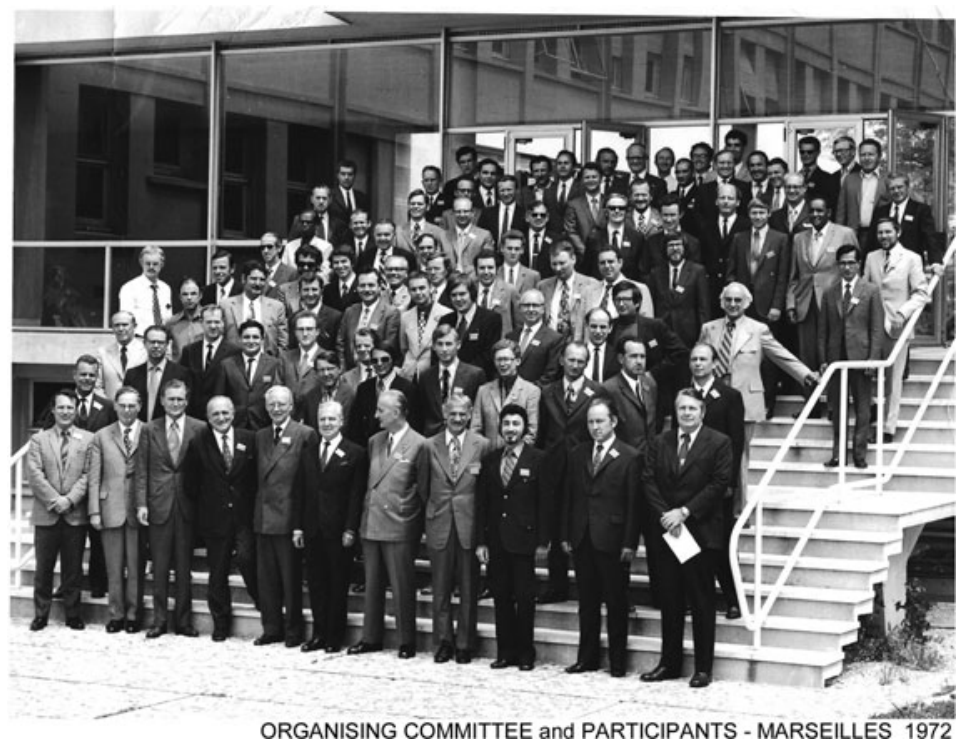


The general satisfaction with the first symposium encouraged the original group to continue, and the second symposium was organised in Sheffield, UK, from 24-29 March 1974. The growing success led to the third symposium, which was organised in München, Germany, from 7-12 March 1976 with a growing interest from industry and research group participation. An international board was formed after the second symposium and we felt that we could run the symposia independently from the International Council of the Aeronautical Sciences. The starting support of ICAS is gratefully acknowledged. A shift of the two-year cycle was made in-order to alternate with ICAS, allocating odd-numbered years to ISABE. This multi-decade-long tradition will be continued in ISABE 2017 in Manchester, UK. This ISABE Special Issue of The Aeronautical Journal offers a technical selection from the wide range of topics covered and of the international flavour of ISABE. The collaboration between ISABE and the Royal Aeronautical Society is expected to continue into the 2019 ISABE Symposium in Canberra, Australia, and hopefully beyond.

ISABE aims to disseminate and encourage aerospace knowledge. The knowledge needed to deliver increasingly efficient, economical and environmentally-friendly propulsion systems will give rise to many exciting and challenging careers. It is significant to note that a modern civil aircraft engine commands a price worth several times the value of its weight in silver. Much of this value stems from the knowledge needed to conceive, design, develop, certify and maintain it. Increasingly, concern for the environment gives rise to large investments in propulsion technology. As a result, the industry will continue to demand highly talented young individuals to meet and overcome the challenges facing the propulsion community. Many illustrious individuals have received ISABE awards on the basis of their technical contributions. Their names are listed below; one hopes they will be an inspiration to young individuals to consider careers within the propulsion community and deliver outcomes that will be valued by future generations.

\section{ISABE AWARDS}

\section{Symposium Location}

1987

1989

1991

1993

1995

1997

1999

2001

2003

2005

2007

2009

2011

2013

2015
CINCINNATI, OHIO, US

ATHENS, GREECE

NOTTINGHAM, UK

TOKYO, JAPAN

MELBOURNE,

AUSTRALIA

CHATTANOOGA, TENNESSEE, US

FIRENZE, ITALY

BANGALORE, INDIA

CLEVELAND, OHIO, US

MUNCHEN, GERMANY

BEIJING, CHINA

MONTREAL, QUEBEC, CANADA

GÖTEBORG, SWEDEN

BUSAN, SOUTH KOREA

PHOENIX, ARIZONA, US

\section{Recipient of the ISABE Award}

Dr HANS VON OHAIN, US

Sir FRANK WHITTLE, UK

Dr ANSELME FRANZ, US

Mr GERHARD NEUMANN, US

Dr G.M. LEWIS, UK

Dr R. MARGUET, FRANCE

Dr V. CHEPKIN, RUSSIA

Dr LEROY SMITH, US

Sir JOHN HORLOCK, UK

Dr TOM CURRAN, US

Professor MATSUKI, JAPAN

Professor J. KERREBROCK, US

Dr Sc LEONID S. YANOVSKIY, RUSSIA

Professor ZHAO XIAOLU, CHINA

Dr ANTHONY J. STRAZISAR, US 
In the 2017 conference, many high-technology aspects are being dealt with. These include advances in power plant components, accessories, whole engine performance assessment and a wide range of integration aspects. An exciting topic that is attracting a large amount of attention is hybrid electric distributed propulsion. This promises to be a disruptive technology that will bring about vast changes in the aerospace field. There are several presentations on this topic from many key world players. Hybrid electric distributed propulsion confers benefits through improved propulsive efficiency and better energy, aerodynamic and structural integration. It faces significant weight, complexity and control challenges. These will give rise to large multidisciplinary investments and activities to achieve large economic and environmental benefits.

Beyond the detailed technical presentations, there is an extensive programme of very senior international aerospace speakers covering many aspects of the value chain of aerospace. These experienced individuals are sharing with us relevant aspects of their valuable knowledge and the promising projections for the future of air-breathing propulsion.

So whether you are an experienced technologist, an eminent scientist, an active researcher, a busy commercial executive or a young person seeking career inspirations, you will find many interesting and challenging topics at ISABE 2017.

F.A.E. Breugelmans

Founding Administrative Secretary 